\title{
Immaginario e immaginazione nel Medioevo, a cura di Maria Bettetini e Francesco Paparella con la collaborazione di Roberto Furlan
}

\section{Walter Meliga}

\section{(2) OpenEdition}

\section{Journals}

\section{Edizione digitale}

URL: http://journals.openedition.org/studifrancesi/3622

DOI: 10.4000/studifrancesi.3622

ISSN: 2421-5856

\section{Editore}

Rosenberg \& Sellier

\section{Edizione cartacea}

Data di pubblicazione: 1 décembre 2012

Paginazione: 537

ISSN: 0039-2944

\section{Notizia bibliografica digitale}

Walter Meliga, «Immaginario e immaginazione nel Medioevo, a cura di Maria Bettetini e Francesco Paparella con la collaborazione di Roberto Furlan», Studi Francesi [Online], 168 (LVI | III) | 2012, online dal 30 novembre 2015, consultato il 05 mars 2021. URL: http://journals.openedition.org/studifrancesi/ 3622 ; DOI: https://doi.org/10.4000/studifrancesi.3622

Questo documento è stato generato automaticamente il 5 mars 2021.

\section{cc) (†)}

Studi Francesi è distribuita con Licenza Creative Commons Attribuzione - Non commerciale - Non opere derivate 4.0 Internazionale. 
Immaginario e immaginazione nel Medioevo, a cura di Maria Bettetini e Francesco Paparella con la collaborazione di Roberto Furlan

\author{
Walter Meliga
}

\title{
NOTIZIA
}

Immaginario e immaginazione nel Medioevo. Atti del Convegno della Società Italiana per lo Studio del Pensiero Medievale (S.I.S.P.M.). Milano, 25-27 settembre 2008, a cura di Maria BETTETINI e Francesco PAPARELLA con la collaborazione di Roberto FURLAN, Louvainla-Neuve, Fédération Internationale des Instituts d'Études Médiévales, 2009 («Textes et études du Moyen Âge», 51), pp. 428.

1 I contributi di questo interessante convegno toccano vari aspetti dell'immaginario medievale (l'impero, i monstra, la fisiognomica) e dell'immaginazione come facoltà della mente umana e delle intelligenze superiori e utile a indagare anche le realtà superiori, nella riflessione dei filosofi (Agostino, Alberto Magno, Tommaso d'Aquino), nel processo creativo dei poeti (Dante) e nel suo rapporto con la magia. 